\title{
Vrednotenje življenjskega sloga in prostorsko oskrbnih potreb starejših
}

\author{
Marta Kavšek ${ }^{*}$ \\ Fakulteta za organizacijske študije v Novem mestu, Novi trg 5, 8000 Novo mesto, Slovenija \\ marta.kavsek@gmail.com
}

Marija Ovsenik

Fakulteta za organizacijske študije v Novem mestu, Novi trg 5, 8000 Novo mesto, Slovenija mara.ovsenik@gmail.com

\section{David Bogataj}

University of Padua, Department of Management and Engineering, Stradella San Nicola 3,

\author{
36100 Vicenza, Italija \\ david.bogataj@unipd.it
}

\begin{abstract}
Povzetek:
Raziskovalno vprašanje (RV): Starejši ljudje postanejo odvisni od pomoči drugih pri različnih starostih. Vprašanje je, katere aktivnosti življenjskega sloga, ki še niso dobro raziskane, vplivajo na njihovo sposobnost samooskrbe. Zato smo želeli preučiti zlasti vpliv težkega fizičnega dela na delovnem mestu na starost ob vstopu v institucionalno oskrbo in v katerem tipu bivališča želijo biti starostniki oskrbovani, ko ne bodo mogli več bivati v lastnem domu.

Namen: Namen članka je odgovoriti na vprašanje, ali življenjski slog - predvsem težko fizično delo - vpliva na starost ob vstopu v dolgotrajno oskrbo in v katerem tipu bivališča želijo biti starostniki oskrbovani, ko ne bodo mogli več bivati v lastnem domu. Ugotovitvi sta pomembni pri oblikovanju projekcij povpraševanja po storitvah dolgotrajne oskrbe. Na podlagi teh ugotovitev se dolgoročno načrtujejo kapacitete dolgotrajne oskrbe, potrebni človeški viri in grajeni prostor za zagotavljanje kakovostne oskrbe oseb, ki so odvisne od pomoči drugih.

Metoda: Anketirali smo 198 starostnikov, in sicer 100 stanovalcev v slovenskih domovih za starostnike ter 98 uporabnikov pomoči in nege na domu. Anketirance smo razvrstili v različne skupine po življenjskem slogu in še posebej preučili vrsto dela, ki so ga opravljali v aktivni dobi. Test vpliva življenjskega sloga na razlike v starosti ob vstopu v oskrbo smo izvedli z z+4 testom tako za preveritev prve kot tudi druge hipoteze. Predstavili smo tudi primer modela izdatkov za dolgotrajno oskrbo.

Rezultati: Prišli smo do dveh pomembnih zaključkov in sicer, da težko fizično delo značilno vpliva na zgodnejši vstop $\mathrm{v}$ institucionalno oskrbo. Z veliko zanesljivostjo lahko trdimo, da se večji del starostnikov ne želi starati na domu, ko pridejo do stanja, da ne morejo več skrbeti sami zase, kar nasprotuje ugotovitvam Evropske komisije.

Organizacija: Ugotovitev, da postanejo delavci, ki so opravljali posebno težka dela, odvisni od pomoči drugih mnogo prej, kar je povezano tudi z večjimi izdatki za oskrbo, je nova. V članku je razvit inovativen primer modela za ovrednotenje razlik $\mathrm{v}$ teh izdatkih, ki je lahko podlaga za izračun zavarovalne premije za predčasno poklicno dolgotrajno oskrbo.
\end{abstract}


Družba: Za kakovostno izvajanje storitev dolgotrajne oskrbe mora družba nameniti ustrezna sredstva oziroma ustrezen delež v BDP, pri tem pa bi del bremena morali nostiti tudi delodajalci dejavnosti s posebno težkimi delovnimi mesti.

Originalnost: Pokazali smo, kako preko poznavanja življenjskega sloga prebivalstva - teže fizičnega dela, bolje načrtujemo potrebe po storitvah in grajenem prostoru ter oskrbovalnih mrežah za starostnike.

Omejitve/nadaljnje raziskovanje: Glede na ranljivost preučevane populacije smo uspeli pridobiti odgovore le od manjšega števila starostnikov, posledično so ocene parametrov slabše, vendar nedavno razvit z+4 test omogoča dokaj zanesljivo oceno vpliva teh parametrov na stroške oskrbe.

Ključne besede: dolgotrajna oskrba, življenjski slog, oskrba na domu, oskrbovana stanovanja, institucionalna oskrba, socialnovarstveni zavod, upad funkcionalnih zmožnosti, stanovanjske skupnosti starostnikov.

\section{Uvod}

Dolgotrajna oskrba v Sloveniji še ni sistemsko urejena, pač pa se zagotavlja v okviru različnih zakonodaj oz. prek ločenih sistemov socialne varnosti. Na to pomanjkljivost opozarja tudi nedavni Evropski semester za Slovenijo. Zakon, ki bo urejal to področje, je v pripravi že vrsto let, zadnji osnutek zakona pa je prišel v javno razpravo leta 2017 (Predlog zakona o dolgotrajni oskrbi, 2017; Colombo, Llena Nozal, Mercier \& Tjadens, 2011, str. 11-12; Rant, 2012, str. 33-42; Hvalič Touzery, 2007, str. 109-122).

Pogosto je upad funkcionalnih zmožnosti rezultat življenjskega sloga, ki vpliva na samostojnost pri opravljanju temeljnih življenjskih funkcij. Obstajajo številne študije (European Commission, 2007; Prakash et al., 2016, str. 997-1007; Paz Ballesteros, Monterrubio Flores, Flores Rivera, Corona Vazquez \& Hernandez Giron, 2017, str. 113-120; Breda \& Watts. 2017; Jacob et al., 2016, str. 1) o tem, kako kajenje, pitje alkohola in pomanjkanje rekreacije kot indikatorji življenjskega sloga vplivajo na upadanje funkcionalnih zmožnosti prebivalstva (Lund, Iversen \& Poulsen, 2001; Siegel, 2012, str. 322; Paul, Ribeiro \& Teixeira, 2012, str. 10; Kohli, 2014, str. 81-111; Lah et al., 2013, str. 29), ni pa dovolj raziskano, kako težko fizično delo v aktivni dobi vpliva na upadanje funkcionalnih zmožnosti in predvsem na stroške dolgotrajne oskrbe (DO) oziroma na nastanek odvisnosti od pomoči drugih.

EUROBAROMETER (2007) trdi, da si velika večina Evropejcev želi starati v lastnem domu in ne $\mathrm{v}$ institucionalni oskrbi. Zato je Evropski parlament izdal resolucijo o deinstitucionalizaciji, ki ji sledi Resolucije o nacionalnemu programu socialnega varstva 2103-2020 (Državni zbor RS, 2013). Na podlagi usmeritev Resolucije o nacionalnemu programu socialnega varstva, ki je upošteval evropske smernice za prehod od institucionalnega varstva k skupnostni oskrbi je Ministrstvo za delo, družino, socialne zadeve in enake možnosti naročilo študijo priprave izhodišč za dezinstitucionalizacijo v Sloveniji (Flacer et al., 2015). 
Naše izkušnje ob večletnem spremljanju starostnikov $\mathrm{v}$ domu starejših občanov nam narekujejo, da je trditev EUROBAROMETRA (2009) in iz njega izpeljane Resolucija Evropskega parlamenta o dolgotrajni oskrbi, o pretežni želji bivanja starostnikov v lastnem domu, v katerem so starostniki bivali v času popolne mobilnosti, vsaj za Slovence vprašljiva in da velja podrobneje preučiti postopke deinstitucionalizacije v Sloveniji in predvsem na temelju ponovnih statističnih opazovanj poiskati pravo pot za izgradnjo socialne infrastrukture za starostnike.

Namen in cilji našega raziskovanja so:

- ugotoviti, kakšen je vpliv življenjskega sloga v posameznih starostnih obdobjih na sposobnost samooskrbe;

- raziskati dejavnike, ki vplivajo na DO skozi življenjski slog starostnika;

- odgovoriti na vprašanje, kako optimalno prilagajati grajeno okolje starostnikom tudi v dolgoročnih načrtih prostorskega razvoja, in ugotoviti, kakšne so optimalne storitve za ohranjanje samostojnosti pri opravljanju temeljnih življenjskih aktivnostih starostnikov ter kakšna je pri tem neto sedanja vrednost bodočih stroškov oskrbe do smrti starostnika, ob tem pa razviti model izdatkov DO, s katerim bomo hipotezo sprejeli ali zavrnili.

\section{Teoretična izhodišča}

Glede na hitro rastoče povpraševanje po gradnji novih domov za starejše, povečanjem zmogljivosti $\mathrm{v}$ obstoječih domovih, negovalnih oddelkih bolnišnic, $\mathrm{s}$ podaljšanim bolnišničnim zdravljenjem, paliativno oskrbo, oskrbo in pomoč na domu ne zagotavljamo potrebnih kapacitet po DO, ki se bodo v naslednjih letih še povečale (Mali, 2009, str. 95-106; Rupel \& Ogorevc, 2010, 2011, str. 1-12).

Slovenija se sooča z demografskim upadanjem in staranjem prebivalstva. Študija Ageing report 2018, ki je izšla junija 2018 (European Commission, 2018), podaja projekcije staranja slovenskega prebivalstva $\mathrm{v}$ obdobju med letoma 2016 in 2070, ko naj bi se pričakovano trajanje življenja ob rojstvu za moške povečalo za 7,6 leta (z 78,2 leta v letu 2016 na 85,8 leta v letu 2070). Pri ženskah se pričakuje, da se bo pričakovano trajanje življenja ob rojstvu v Sloveniji povečalo za 6,3 leta (s 83,8 leta v letu 2016 na 90,1 leta v letu 2070), glej tabelo 1.

V Sloveniji se pričakuje, da se bo pričakovano trajanje življenja 65-letnih moških v obdobju projekcij povečalo za 5,4 leta, in sicer s 17,7 leta v letu 2016 na 23,1 leta do leta 2070. Za ženske se pričakuje, da se bo pričakovano trajanje življenja v starosti 65 let povečalo za 5 let - z 21,4 leta iz leta 2016 na 26,4 leta do leta 2070. To bo znatno vplivalo na povečanje deleža starejših prebivalcev Slovenije.

Tabela 1. Projekcije pričakovanega trajanja življenja v obdobju 2016-2070

\begin{tabular}{llllllll}
\hline \multicolumn{7}{l}{ Pričakovana življenjska doba ob rojstvu } \\
\hline Leto & 2016 & 2020 & 2030 & 2040 & 2050 & 2060 & 2070 \\
\hline Moški & 78,2 & 78,9 & 80,4 & 81,9 & 83,3 & 84,6 & 85,8
\end{tabular}




\begin{tabular}{lrrrrrrr} 
Ženske & 83,8 & 84,4 & 85,7 & 86,9 & 88,0 & 89,1 & 90,1 \\
\hline
\end{tabular}

Opomba. Prirejeno iz The Aging Report (2018). Evropska komisija 2018.

V različnih zakonskih aktih, podzakonskih aktih in pravilnikih so opredeljene pravice in postopki uveljavitve teh do storitev in denarnih prejemkov, ki jih potrebujejo osebe, odvisne od pomoči drugih. Prejemniki morajo uveljavljati pravice $\mathrm{v}$ različnih ustanovah. Za uveljavljanje posameznih pravic ne obstajajo enotna merila, raven pomoči, ki jo posameznik prejema, pa ni vedno usklajena z njegovimi dejanskimi potrebami. (Kopač Mrak, Levanič \& Dominkuš, 2015).

Skladno z razvojem dolgotrajne oskrbe bo treba zagotoviti zadostno število usposobljenih in kompetentnih delavcev, in sicer $\mathrm{v}$ ustreznih delovnih pogojih ter $\mathrm{v}$ dostojnih in stabilnih delovnih okoljih (WHO, 2006, str. 36). Vlaganje v človeški kapital bo pripomoglo k obvladljivi obremenitvi. Ustrezno podporno okolje bi bilo treba zagotoviti tudi za prostovoljce in neformalne oskrbovalce (Resolucija Evropskega parlamenta o dolgotrajni oskrbi, 2016, str. 1-22).

Lund, Iversen in Poulsen (2001, str. 1) so v raziskavi prepoznali dejavnike tveganja na delovnem mestu $\mathrm{v}$ delovnem okolju, kjer težko fizično delo povzroči: odpoved zaposlitve, spremembo delavnega mesta, brezposelnost, dolgotrajni bolniški stalež, invalidsko pokojnino in predčasno upokojitev. Prakash in sodelavci (2016, str. 997-1007) so spremljali zaposlene v javni upravi na Finskem. Ti so dokazali, da so bili delovni pogoji, ki so bili povezani predvsem s fizično težkim delom, močnejši napovedovalci invalidnosti v poznejšem življenju. Pri ženskah je pisarniško delo povečalo tudi tveganje invalidnosti (Prakash et al., 2016, str. 997-1007). Zloraba alkohola in zasvojenost od drog se po Siegel (2012 v Nicholson et al., 2004, str. 322) obravnavata kot pojava, ki sta škodljiva za zdravje. Paz Ballesteros, Monterrubio Flores, Flores Rivera, Corona Vazquez in Hernandez Giron, (2017, str. 113-120) $\mathrm{v}$ raziskavi dokazujejo, da je kajenje povezano s hitrim napredovanjem invalidnosti in da bi prenehanje uživanja tobaka in alkohola lahko bilo klinično koristno.

V oskrbovanih stanovanjih starejši ljudje živijo razmeroma samostojno življenje ob večji ali manjši pomoči strokovnega osebja. Pri tem gre za oskrbovana stanovanja, kjer se storitev izvaja $\mathrm{v}$ funkcionalno povezanih in potrebam starejših ljudi prilagojenih stanovanjih in je oblika institucionalnega varstva $\mathrm{v}$ skupnosti (Standardi in normativi socialnovarstvenih storitev, 2010, 6. čl; Nagode, Zver, Marn, Jacović \& Dominkuš, 2014, str. 9).

Stanovanjske skupnosti in gospodinjske skupnosti predstavljajo obliko bivanja, pri kateri različni ljudje skupaj stanujejo v istem stanovanju ali hiši. Vsak stanovalec ima svoj lastni bivalni prostor - sobo ali celo stanovanje. Poleg tega obstaja še nekaj prostorov, ki jih uporabljajo kot skupne. Model samoupravnih skupnih gospodinjstev s stanovanji brez arhitektonskih ovir se je uveljavil kot nov trend pri projektih bivanja v skupnosti (Štuhec \& Fras, 2010, str. 3-15). 
Na podlagi pregleda literature smo postavili naslednje hipoteze:

- Hipoteza 1: Upad funkcionalnih zmožnosti starostnikov je odvisen od teže dela na delovnem mestu.

Pri prebiranju strokovne literature smo prišli do mnogih zaključkov, kako kajenje, pitje alkohola in zanemarjanje telesnih aktivnosti (vadbe) vplivajo na slabše zdravje prebivalstva, pri pregledu literature $\mathrm{v}$ znanstvenih bazah pa vseeno nismo zasledili člankov, katerih izsledki bi kazali, kako obremenitve na delovnem mestu-teža dela vpliva na starost ob vstopu v dolgotrajno oskrbo in stroške v povezavi z dolgotrajno oskrbo.

V literaturi, ki smo jo preučili, nismo zasledili raziskav, ki bi preučevale upad funkcionalnih zmožnosti.

- Hipoteza 2: Posamezni kazalniki življenjskega sloga so različno pomembni za oblikovanje upada funkcionalnih zmožnosti.

Pri upadu funkcionalnih zmožnosti smo opazovali predvsem starost - kdaj so se morali starejši prebivalci odločiti za oskrbo v domu starejših občanov. Razlike med povprečnimi starostmi ob vstopu so se kazale tako pri kajenju, pitju alkohola kot tudi pri telesnih aktivnostih, vendar pri nekaterih kazalnikih bolj, pri nekaterih pa manj značilno.

- Hipoteza 3: Zaradi upada funkcionalnih zmožnosti se potrebe po prostorskih kapacitetah posameznih vrst gradenj za starejše prebivalstvo in kapacitete človeških virov v oskrbovalnih mrežah za starostnike razlikujejo, na podlagi česar sklepamo, da življenjski slog vpliva na neto sedanjo vrednost stroškov oskrbe starostnikov.

Stroški oskrbe so odvisni od starosti ob vstopu v DO in kategorije potrebne oskrbe. Pokazalo pa se je, da so želje po vrsti bivališča tistih, ki zahtevnejše oskrbe še ne potrebujejo, drugačne od tistih, ki so že pred dejstvom, da potrebujejo intenzivnejšo oskrbo.

\section{Metoda}

Slika 1 prikazuje povezavo med vrednotenjem življenjskega sloga in prostorsko oskrbnih potreb starostnikov s posameznimi hipotezami. Upad funkcionalnih zmožnosti starostnikov je odvisen od življenjskega sloga starostnikov $\mathrm{v}$ aktivnem življenjskem obdobju, kar dokazujemo s hipotezo H1. Nad krivuljo prikazujemo vpliv dejavnikov življenjskega sloga: 
kajenje, alkohol, telesna aktivnost in težko fizično delo na upad funkcionalnih zmožnosti, kar dokazujemo s hipotezo H2. Zaradi upada funkcionalnih zmožnosti se potrebe po prostorskih kapacitetah posameznih vrst gradenj za starejše prebivalstvo in kapacitete človeških virov v oskrbovalnih mrežah za starostnike razlikujejo, na podlagi česar sklepamo, da življenjski slog vpliva na neto sedanjo vrednost stroškov oskrbe starostnikov in dokazujemo s hipotezo H3.

Pri kvantitativni analizi podatkov smo uporabili računalniško orodje Excel in program SPSS. Zaradi zaščite osebnih podatkov smo težko dobili navedeno število anketirancev, ki je zato majhno, zato smo poleg Pearsonovega hi-kvadrat testa uporabili tudi novo metodo za testiranje struktur in razlik v deležih v primeru manjših vzorcev - to je t. i. »z plus štiri test« (angl.: z plus four test).

Za ovrednotenje in primerjavo denarnih tokov, povezanih z oskrbo oseb, ki so delale na težkih delovnih mestih, in tistih, ki niso delale na težkih delovnih mestih, smo uporabili aktuarsko formulo 4.5 (Gerber, 1996 str. 48). Gre torej za primer modela izračuna neto sedanje vrednosti, v nadaljevanju (NSV).

Izdelali smo anketni vprašalnik, ki ga je v smislu dovoljenja za raziskavo potrdila etična komisija Fakultete za organizacijske študije (FOŠ) . Opravili smo osebne razgovore z anketiranci. Predpostavljali smo, da bo uspešnost odgovarjanja anketirancev visoka in da bomo lahko sproti razrešili vse dileme.

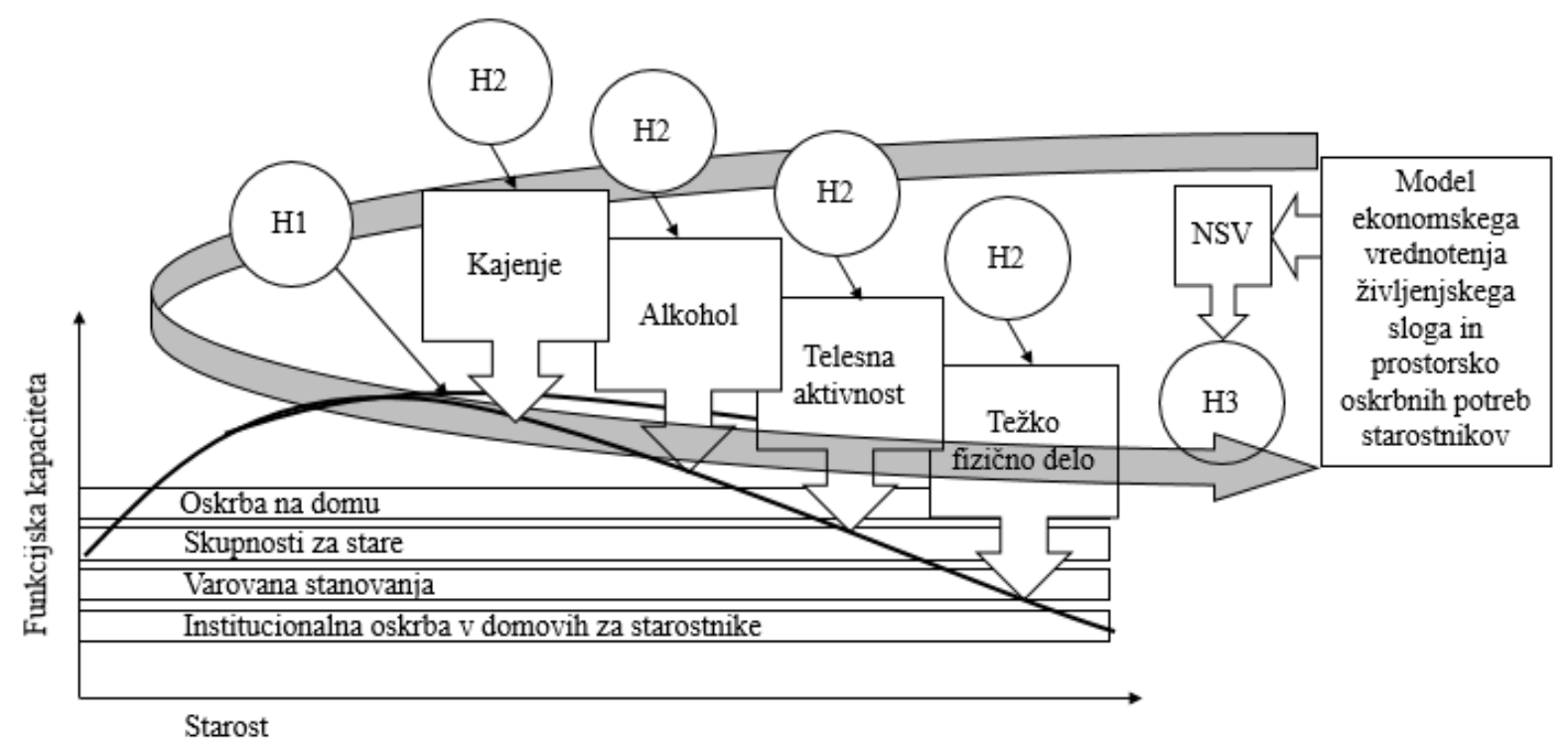

Slika 1. Model raziskave ekonomskega vrednotenja življenjskega sloga in prostorsko oskrbnih potreb starostnikov

V štirih slovenskih občinah (posavska regija, savinjska regija, belokrajnska in dolenjska regija) smo anketirali 198 starostnikov, od tega 100 stanovalcev v slovenskih domovih za 
starostnike ter 98 oseb v oskrbi na domu (98 anketiranih oseb). Povprašali smo jih o njihovem življenjskem slogu in prehodih med bivališči glede na starost. Anketirance smo razvrstili v različne skupine po življenjskem slogu in še posebej preučili vrsto dela, ki so ga opravljali v aktivni dobi. Posamezne kombinacije lastnosti po CDS smo povezovali v izbrane skupine stanj ter ta stanja povezali s potrebami po ustreznih bivališčih in oskrbi, pri čemer smo ugotavljali ustreznost prilagoditve bivališča posameznemu stanju.

Upoštevali smo določena merila za izključitev oseb, ki niso primerne za sodelovanje v raziskavi. Mednje so sodili: preveč bolni, da bi sodelovali; posamezniki s hudimi govornimi ali slušnimi motnjami, saj z njimi ni možna normalna komunikacija; posamezniki, ki se soočajo z depresivnim stanjem, za katere bi bila anketa boleča; osebe $\mathrm{z}$ demenco, ker bi bila komunikacija z njimi otežena; osebe, ki so zmedene ali imajo kakšno drugo obliko duševne motnje. Izbrani uporabnik je imel možnost odkloniti raziskavo pred in med samim anketiranjem.

Ker starejši ljudje nimajo dovolj tehnološkega znanja in izkušenj, nam anket niso izpolnili sami, temveč smo jih izpolnjevali ob pogovoru z njimi. Tako smo jih seznanili z namenom raziskave in od njih pridobili soglasje. Vprašanja so bila enostavna in tudi veliki večini starejših oskrbovancev razumljiva. Anketiranci so si med anketiranjem lahko premislili in odstopili od sodelovanja ali pa so se odločili, da pri določenem vprašanju ne bodo podali odgovora.

Uporabniki so bili prejemniki socialnovarstvenih storitev s področja pomoči in nege na domu, ki jo izvajajo domovi starejših občanov kot eno izmed dejavnosti. Vodstvo doma je podalo pisno soglasje za anketiranje in tako smo se dogovorili o merilih izključenosti. Upoštevali smo dogovorjena merila za izključitev.

Druga skupina anketirancev, ki so sicer deležni oskrbe na domu, je bila anketirana na lastnem domu. Delavke, ki delajo na področju socialnovarstvene storitve pomoči in nege na domu, svoje uporabnike storitev dobro poznajo in vsakodnevno vstopajo $\mathrm{v}$ njihove domove. $\mathrm{V}$ sodelovanju s koordinatorko pomoči na domu so določile sezname uporabnikov, ki so bili statistične enote našega vzorca. Na skupnem sestanku izvajalcev nege na domu so bile izvajalke seznanjene s ciljem raziskave. Določili smo merila izključenosti in pridobili prostovoljno privolitev v sodelovanje izvajalk nege na domu. Sodelovanje pri anketi je potekalo v pisni obliki. Pri vprašanjih, ki so zahtevala ustne odgovore, so izvajalke nege na domu te zapisale na anketni list. Največja ovira pri izvajanju anket je bil čas izvedbe, kajti uporabniki storitev plačujejo oskrbo na uro in želijo optimalno storitev zase. Zato so izvajalci za pomoč večkrat prosili tudi svojce. 


\section{Rezultati in razprava}

\subsection{Demografija}

Študija združuje rezultate vzorcev anketirancev v domu starejših občanov in negi na domu $(\mathrm{n}=198)$. Anketiranci so bili stari od 51 do 95 let. V vzorcu so bile zastopane ženske 127 (64 \%) in moški 71 (36 \%). V domu starejših občanov je bilo anketiranih 42 moških in 58 žensk, v okviru nege na domu pa je bilo anketiranih 29 moških in 69 žensk. Polovica anketirancev je bila stara med 76 in 90 let. Slika 2 prikazuje delež anketirancev po starosti v domovih starejših občanov. Večina vprašanih je imela končano osnovnošolsko izobrazbo (62\%), $21 \%$ jih je imelo poklicno izobrazbo, $13 \%$ srednjo izobrazbo in $3 \%$ višjo ali univerzitetno. Na podlagi socialno-ekonomskega vidika ugotavljamo, da pri $27 \%$ anketirancev mesečni dohodek znaša od 301 do $500 € .26 \%$ anketirancev mesečno prejme manj kot $300 €$ pokojnine, $24 \%$ anketirancev pa ima pokojnino, ki je višja od $501 €$ in nižja od $800 €, 12,5 \%$ anketirancev je imelo dohodek med $801 €$ in $1.500 €$, kot prikazuje tabela 2 . Želena bivališča so odvisna od višine starostne pokojnine.

Tabela 2. Število starostnikov, ki prejemajo pomoč in nego na domu, vključenih v anketo, po želenem tipu bivališča in višini pokojnine

\begin{tabular}{|c|c|c|c|c|c|c|c|c|}
\hline $\begin{array}{l}\text { Višina } \\
\text { pokojnine } \\
\text { (v EUR) }\end{array}$ & $\begin{array}{c}\text { Oskrbo- } \\
\text { vano } \\
\text { stanova- } \\
\text { nje }\end{array}$ & $\begin{array}{c}\text { Pritlično } \\
\text { na robu } \\
\text { mesta }\end{array}$ & $\begin{array}{c}\text { Ostal v } \\
\text { obstoje- } \\
\text { čem } \\
\text { stanovanj } \\
\text { u } \\
\end{array}$ & $\begin{array}{c}\text { Stano- } \\
\text { vanjska } \\
\text { skupnost } \\
\text { za stare }\end{array}$ & $\begin{array}{c}\text { Dom } \\
\text { starejših } \\
\text { občanov }\end{array}$ & $\underset{\text { odgovora }}{\mathrm{Ni}}$ & Skupaj & $\%$ \\
\hline Do 300 & 5 & 2 & 8 & & & 11 & 26 & 26,5 \\
\hline $301-500$ & 6 & 2 & 9 & & & 10 & 27 & 27,5 \\
\hline 501-800 & 7 & 2 & 7 & & & 8 & 24 & 24,5 \\
\hline $801-1.500$ & 6 & 2 & 4 & & & 1 & 12 & 12,5 \\
\hline Nad 1.501 & & & & 1 & & & 2 & 2,0 \\
\hline Ni odgovora & 1 & & & & 1 & 5 & 7 & 7,0 \\
\hline Skupaj & 25 & 8 & 28 & 1 & 1 & 35 & 98 & 100 \\
\hline
\end{tabular}

Delež starostnikov v DSO-jih od 81 do 95 let predstavlja $43 \%$ anketirancev. 


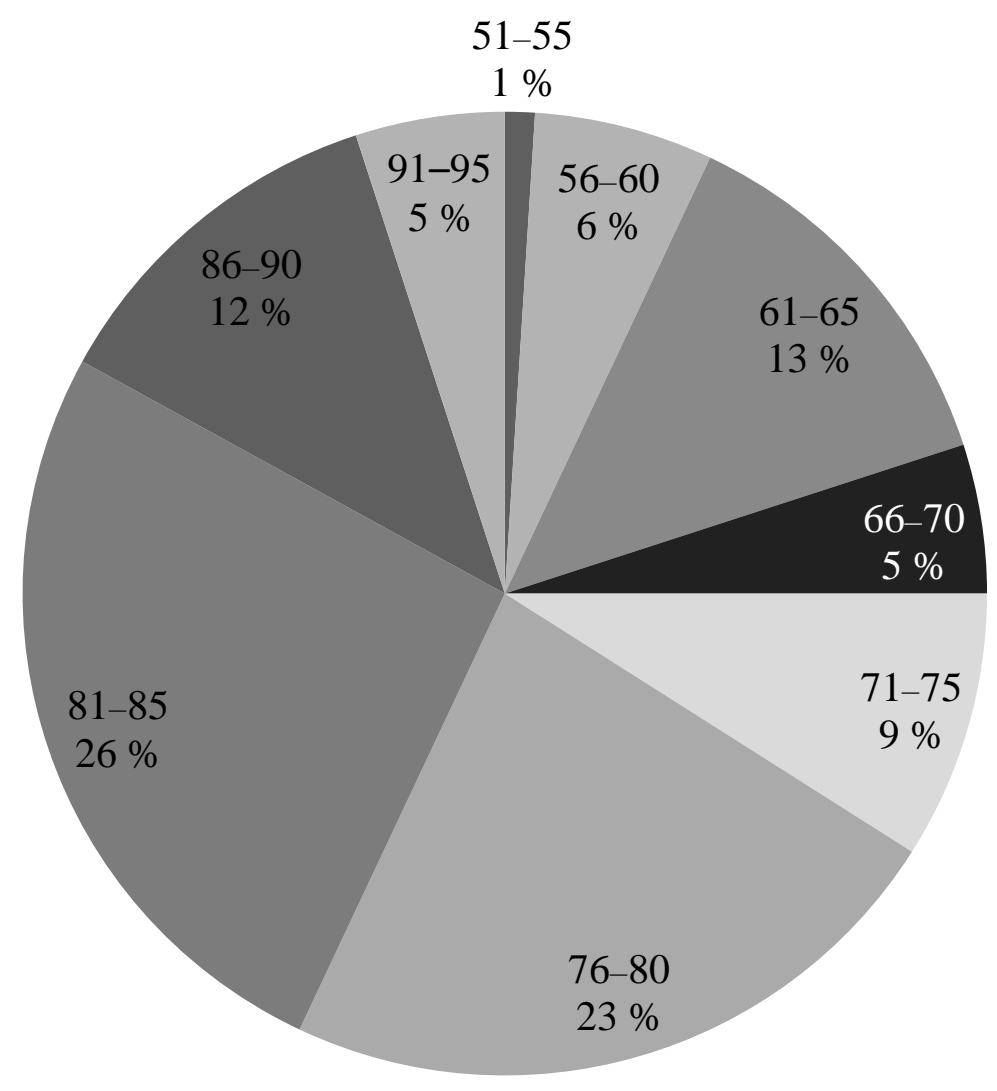

Slika 2. Deleži anketirancev v DSO po starosti

\section{2 Življenjski stil}

$\mathrm{S}$ tveganjem, manjšim od $(\alpha<0,12)$, lahko trdimo, da moški, ki pijejo več, pridejo v institucionalno oskrbo pred 70. letom starosti z večjo verjetnostjo kot tisti, ki ne kadijo. S tveganjem, manjšim od $(\alpha<0,07)$, lahko trdimo, da ženske, ki pijejo več, pridejo $\mathrm{v}$ institucionalno oskrbo pred 70. letom starosti z večjo verjetnostjo kot tiste, ki ne pijejo ali zmerno pijejo alkoholne pijače. S tveganjem, manjšim od $(\alpha<0,09)$, lahko trdimo, da moški, ki kadijo, z večjo verjetnostjo pridejo v institucionalno oskrbo pred 70. letom starosti.

S tveganjem $(\alpha=0,25)$ lahko trdimo, da ženske, ki kadijo, $\mathrm{z}$ večjo verjetnostjo pridejo $\mathrm{v}$ institucionalno oskrbo pred 70. letom. To tveganje bi bilo preveliko. Razlike niso statistično značilne, zato se bomo takim trditvam v bodoče izogibali, če ne bomo imeli možnosti za povečanje vzorca in preveritev rezultatov z večjo zanesljivostjo.

Trdimo, da postanejo tisti delavci, ki so delali na težkih fizičnih delovnih mestih, prej odvisni od pomoči drugih, pri čemer je tveganje $(\alpha=0,03)$. Tega pa ne moremo trditi o ženskah $-\mathrm{v}$ vzorec je namreč težko zajeti delavke, ki bi delale na fizično zelo obremenjujočih delovnih mestih. Ugotovili smo, da med telesno bolj ali manj aktivnimi ženskami ni značilnih razlik glede starosti ob vstopu v institucionalno oskrbo v domu za starejše občane. Ugotovili smo 
tudi, da moški, ki so na delovnem mestu opravljali težja fizična dela, ki so vključevala več hoje in večje telesne obremenitve, pridejo v dom zaradi bolezni pri nižji starosti. Ženska, ki trpi za štirimi kroničnimi boleznimi, je v dom prišla pred 75. letom starosti, natančneje med 56. in 60. letom starosti. Ob trditvi, da sta starost ob vstopu v dom za starejše in število kroničnih bolezni povezana indikatorja, tvegamo manj kot 2,5\% $(\alpha<0,025)$, čeprav je vzorec majhen. Ženske z več kroničnimi boleznimi prej vstopajo v institucionalno oskrbo.

\subsection{Bivalni prostor}

Anketiranci so se o prednostnem bivalnem prostoru in storitvah odločali takole: $44,4 \%$ starostnikov bi želelo ostati v svojem starem domu v vsakem primeru - ne vidijo ali si ne morejo privoščiti nobene druge rešitve; 39,7 \% starostnikov želi živeti v oskrbovanih stanovanjih; 1,6 \% v skupnosti za stare (v Sloveniji takšna skupnost sicer ne obstaja in zato tudi ni znana, vendar anketiranci menijo, da bi v takšni skupnosti lahko zaščitili svojo neodvisnost in dostojanstvo); 12,7 \% anketirancev bi želelo ostati popolnoma neodvisnih, torej se ne bi vključili v nobeno skupnost, vendar bi potrebovali več storitev, udobja in pritlično stanovanje, se pravi predvsem boljšo dostopnost; le 1,6 \% anketirancev pa bi šlo v dom za ostarele.

Slika 3 prikazuje preference anketiranih moških in žensk po storitvah dolgotrajne oskrbe.

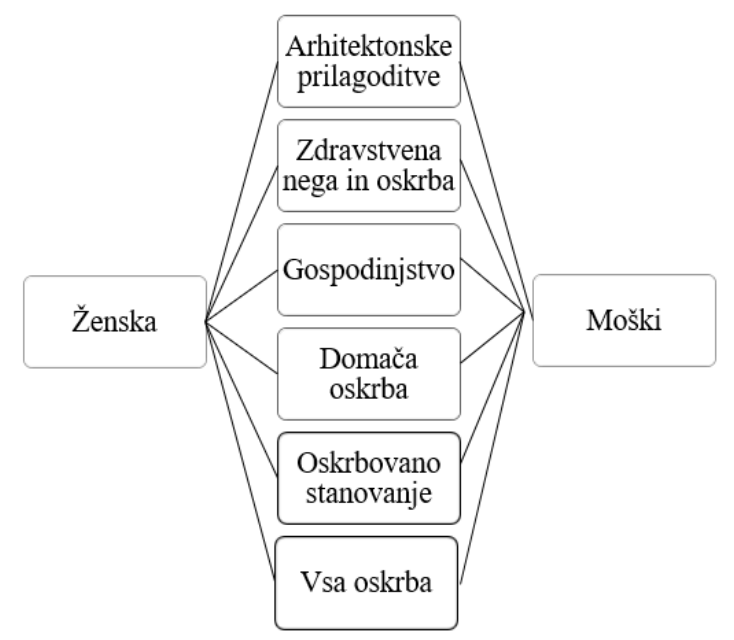

Slika 3. Preference anketiranih moških in žensk po storitvah dolgotrajne oskrbe

Preučili in dokazali smo naslednje tri hipoteze:

- Hipoteza 1 smo potrdili in dokazali, da je upad funkcionalnih zmožnosti starostnikov odvisen od življenjskega sloga starostnikov v aktivnem življenjskem obdobju. Kazalniki življenjskega sloga vplivajo na upad funkcionalnih zmožnosti, sta pokazala podrobnejša raziskava in $\mathrm{v}$ njej uporabljen test $\mathrm{z}+4$, ki nam je kljub majhnemu raziskovalnemu vzorcu omogočil zanesljive zaključke o razlikah. 
S tveganjem, manjšim od $\alpha<0,12$, lahko trdimo, da moški, ki pijejo več, $z$ večjo verjetnostjo pridejo $\mathrm{v}$ institucionalno oskrbo pred 70. letom starosti. S tveganjem, manjšim od $\alpha<0,07$, lahko trdimo, da ženske, ki pijejo več, $z$ večjo verjetnostjo pridejo $\mathrm{v}$ institucionalno oskrbo pred 70. letom starosti. S tveganjem, manjšim od $\alpha<$ 0,09, lahko trdimo, da moški, ki kadijo več, $\mathrm{z}$ večjo verjetnostjo pridejo $\mathrm{v}$ institucionalno oskrbo pred 70. letom starosti. S tveganjem skoraj $\alpha=0,20$ lahko trdimo, da ženske, ki delajo več sede, stoje in z manjšimi obremenitvami, pridejo $\mathrm{v}$ institucionalno oskrbo pred 70. letom z večjo verjetnostjo kot tiste, ki so na delovnem mestu fizično aktivnejše. S tveganjem $\alpha=0,03$ lahko trdimo, da moški, ki delajo na težkih fizičnih delih, pridejo v institucionalno oskrbo pred 70. letom bolj verjetno kot tisti, ki so na delovnem mestu manj fizično aktivni.

- Hipoteza 2 smo potrdili, ker smo dokazali s testom z+4, da kazalniki življenjskega sloga so različno pomembni za oblikovanje upada funkcionalnih zmožnosti.

V naši anketirani populaciji je razlika v starosti ob vstopu v DO med tistimi, ki so opravljali težka dela, in ostalimi štiri leta. Zato smo tudi tu predpostavili to starostno razliko, hkrati pa tudi, da se dvigne starost ob upokojitvi na 65 let, kar velja po zadnjem veljavnem pokojninskem zakonu ZPIZ.

- Hipoteza 3 smo potrdili in ugotovili, da upad funkcionalnih zmožnosti starostnikov (s tem pa tudi potrebe po prostorskih kapacitetah posameznih vrst gradenj in po kapacitetah človeških virov $\mathrm{v}$ oskrbovalnih mrežah za starostnike ter potrebe po denarnih sredstvih za zagotavljanje njihove oskrbe) je odvisen od življenjskega sloga.

Za preveritev tretje hipoteze smo razvili primer modela vrednotenja izdatkov za dolgotrajno oskrbo, ki vključuje parametre osnovne oskrbe, stanovanjske oskrbe, socialne oskrbe in zdravstvene nege, nadalje smo ovrednotili skupne doživljenjske izdatke za dolgotrajno oskrbo z izračunom aktuarske sedanje vrednosti izdatkov.

Oskrbovanec je vstopil v oskrbo štiri leta prej, kar je mogoče pričakovati glede na naše teste razlik starosti ob vstopu. NSV doživljenjske oskrbe oskrbovanca pri 68 letih je $181.555,36 €$. NSV doživljenjske oskrbe oskrbovanca pri 72 letih je 121.241,48 €. Ob predpostavkah, da je sicer pričakovano trajanje življenja pri obeh oskrbovancih po starosti 65 let enako, saj naša statistika ne zaznava razlik v pričakovanem trajanju življenja, že iz izreka o »kmečkih koreninah « pa je pričakovati, da vsaj na podeželju ti ljudje živijo vsaj tako dolgo kot tisti na lažjih delovnih mestih, je pričakovati, da bodo skupni neto sedanji stroški oskrbe starostnikov, ki so opravljali težka dela, še enkrat tolikšni kot za tiste, ki takih težkih del niso opravljali.

Naredili smo povzetek primerjave NSV doživljenjske oskrbe med dvema uporabnikoma dolgotrajne oskrbe ob vstopu v DO pri 68 letih in 72 letih starosti z 
značilno različnim življenjskim slogom, kot prikazuje simulacija modela vrednotenja na sliki 4.

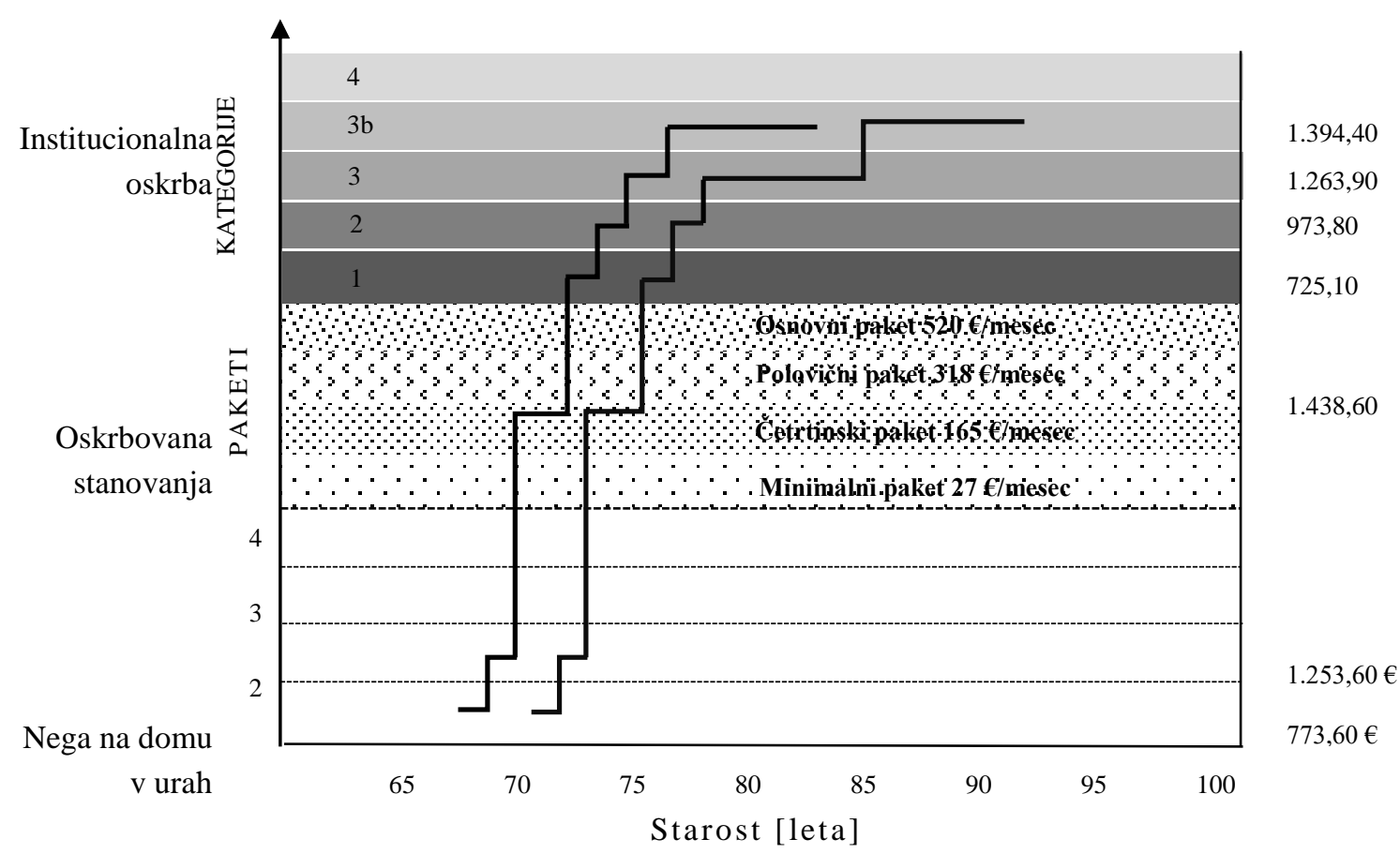

Slika 4. Simulacija modela vrednotenja oskrbe za osebe na težkih fizičnih delih pri 68 letih in 72 letih ob vstopu $\mathrm{v}$ DO

Očitno je, da na starost ob vstopu v dolgotrajno oskrbo vplivajo dejavniki, povezani z življenjskimi razvadami in slogom, kot so: kajenje, pitje alkohola, telesna aktivnost na delovnem mestu ali telesna dejavnost vsak dan. Ta trditev, ki je bila v mnogih delih že dobro raziskana, pa doslej ni vključevala trditve, da delo na fizično posebno težkih delovnih mestih vpliva na zgodnejšo potrebo po institucionalni oskrbi, kar smo dokazali $\mathrm{z}$ veliko zanesljivostjo te trditve. Pokazali pa smo tudi, da na starost ob vstopu vpliva tudi kakovost grajenega okolja, zato bi tudi država morala problematiki neustreznih nastanitev starostnikov posvetiti več pozornosti. Vendar pa ni zanemarljivo dejstvo, da so starostniki odgovarjali na anketna vprašanja ob zavedanju, da so uresničitve njihovih želja odvisne od njihovih finančnih zmožnostih.

\section{Zaključek}

V obstoječi literaturi je sicer mogoče zaslediti, da nekateri dejavniki vplivajo na zdravje prebivalstva, ne pa tudi, ali in kako močno vplivajo na sposobnost samooskrbe. Vrsta aktivnosti na delovnem mestu, med njimi pa predvsem težko fizično delo, značilno vpliva ne samo na obolenja, na kar opozarjajo predvsem nekatere ergonomske raziskave, ampak tudi na starost, ko posameznik postane odvisen od pomoči drugih oziroma pridobi pravico do institucionalne oskrbe, česar še ni bilo mogoče zaslediti v obstoječi literaturi. Medtem ko so bili vplivi življenjskega sloga (kajenje, večurno sedenje pri delu ter pitje alkohola) na zdravje preučevani v tisočih delih, vpliva težkega fizičnega dela kot dejavnika, ki vpliva na zgodnejšo 
potrebo za vstop v dolgotrajno oskrbo, ni preiskoval še nihče. Najdemo le več del o vplivu takšnega dela na bolečine $\mathrm{v}$ križu, poškodbo hrbtenice in podobne posledice, nikjer pa ni izsledkov kakšne raziskave, ki bi preučevala, kako ta vpliva na starost ob pridobitvi pravice do dolgotrajne oskrbe. $Z$ veliko zanesljivostjo lahko trdimo, da težko fizično delo značilno vpliva na zgodnejši vstop v institucionalno oskrbo in da ni res, da se želi večina starostnikov starati na domu, ko pridejo do stanja, ko ne morejo več skrbeti sami zase. Ko se temu približujejo ali že dosežejo takšno stanje upada funkcionalnih zmožnosti, si želijo drugačne oskrbe, in sicer ali v skupnostih - pametnih srebrnih vaseh ali v oskrbovanih domovih, v najslabšem primeru pa $\mathrm{v}$ institucionalni oskrbi $\mathrm{v}$ domu starejših občanov. Zavedati se moramo namreč, da enkratni dnevni obisk starostnika, ki sicer sam leži doma vse dni, ne more zadostiti njegovim elementarnim življenjskim potrebam, zaradi podaljšanja starosti ob upokojevanju pa otroci ne morejo več tako skrbeti za starše, kot so nekoč.

Menimo, da je Evrobarometer 283, ki ga je pozneje povzela tudi Evropska komisija s svojimi predlogi o deinstitucionalizaciji dolgotrajne oskrbe, temeljil na anketi, ki je zajela vse starostne kohorte prebivalstva, vendar o dejanskih željah oskrbovancev lahko več povedo le oskrbovanci sami, zato je EVROBAROMETER dejansko zgrešil svoje cilje. Na podlagi svojih izkušenj in anketiranja na terenu smo prišli do ugotovitve, da si veliko starostnikov tedaj, ko več ne morejo skrbeti sami zase v lastnem domu, želi oskrbe v skupnosti, ki v Sloveniji ni razvita, zato je naša skupna naloga, da za dvig kakovosti življenja starostnikov to vrsto oskrbe tudi razvijamo, za kar so na voljo tudi evropska sredstva.

\section{Reference}

1. Age Platform Europe. (2010, 22. junij). Evropska Listina pravic in odgovornosti starejših, potrebnih dolgotrajne oskrbe in podpore. Pridobljeno na http://www.ageplatform.eu/images/stories/22204AGEcharteeuropeenneSLv2.pdf

2. Eurostat. (2015). EUROSTAT Statistics Explained: People in the EU - population projections. Pridobljeno na https://ec.europa.eu/eurostat/statistics-explained/index.php/People_in_the_EU__population_projections IRRS explained/index.php/People_in_the_EU_\%E2\%80\%93_population_projections

3. Breda, A. I. \& Watts, A. S. (2017). Expectations Regarding Aging, physical activity, and physical function in older adults. Gerontology \& Geriatric Medicine, 3, 1-8. doi: 10.1177/2333721417702350 journals.sagepub.com/home/ggm

4. Colombo, F., Llena Nozal, A., Mercier, J. \& Tjadens, F. (2011). Help Wanted? Providing and Paying for Long - Term Care. Paris: OECD Publishing.

5. Državni zbor Republike Slovenije (2013). Resolucija o nacionalnem programu socialnega varstva za obdobje 2013-2020, Uradni list RS, št. 39/13, na voljo na: http://www.pisrs.si/Pis.web/pregledPredpisa?id=NACP68

6. EUROBAROMETER European Commission. (2007). Health and long-term care in the European Union. Special Eurobarometer 283, Wave 67.3.

7. European Commission. (2008). Dolgotrajna oskrba v Evropski uniji. Luxembourg: Urad za uradne publikacije Evropskih skupnosti. doi: 10.2767/38844 
8. European Commission. (2018). The Ageing Report 2018: Economic and Budgetary Projections for the EU Member States (2016-2070). Luxembourg: Publications Office of the European Union. Pridobljeno na https://ec.europa.eu/info/sites/info/files/economy-finance/ip079_en.pdf. EK, 2018.

9. European Commission. (2017). The Ageing Report 2018. Underlying Assumptions \& Projection Methodologies. Luxembourg: Urad za uradne publikacije Evropskih skupnosti.

10. Flaker, V., Rafaelič,A., Bezjak, S.et al.(2015). Izhodišča deinstitucionalizacije v Republiki Sloveniji - ločeni operativni povzetek. Ljubljana: UL-Fakulteta za socialno delo.

11. Gerber, H. (1996). Matematika življenjskih zavarovanj. Ljubljana: Društvo matematikov, fizikov in astronomov Slovenije.

12. Hvalič Touzery, S. (2007). Osnovna vsakodnevna opravila/dnevne življenjske aktivnosti (ADL). Kakovostna starost, 10(4), 69-70.

13. Inštitut Republike Slovenije za socialno varstvo [IRSSV]. (2014). Pregled izvajanja socialne oskrbe na domu po evropskih državah s poudarkom na ocenjevanju potreb uporabnikov. Pridobljeno na https://www.irssv.si/upload2/PND\%20\%20mednarodni\%20pregled\%20in\%20ocenjevanje\%20potreb_koncno\%20porocilo.pdf

14. Inštitut Republike Slovenije za socialno varstvo [IRSSV]. (2015a). Izvajanje pomoči na domu: Analiza stanja v letu 2014. Ljubljana: MDDSZ.

15. Inštitut Republike Slovenije za socialno varstvo [IRSSV]. (2015b). Oskrbovana stanovanja. Pridobljeno na https://www.irssv.si/socialne-zadeve/dolgotrajna-oskrba-in-varstvostarejsih/oskrbovana-stanovanja

16. Inštitut Republike Slovenije za socialno varstvo [IRSSV]. (2015c). Analiza organiziranosti in izvajanja oskrbe na področju oskrbovanih stanovanj. Pridobljeno na https://www.irssv.si/upload2/Analiza\%20organiziranosti\%20OS_koncno_30.11.2015.pdf

17. Jacob, M. E., Yee, L. M., Diehr, P. H., Arnold, A. M., Thielke, S. M., ... Newman, A. B. (2016). Can a Healthy Lifestyle Compress the Disabled Period in Older Adults? Journal The American Geriatrics Society, 64(10), 1-10. doi: 10.1111/jgs.14314

18. Kohli Bhupinde, P. (2014). Age-Friendliness of the Urban Design Guidelines of the Cities of Kitchener and Waterloo. Ontario: Waterloo, 81-111.

19. Kopač Mrak, A., Levanič, D. \& Dominkuš, D. (2015). Izhodišča za pripravo Predloga zakona o dolgotrajni oskrbi, osebni asistenci in zavarovanju za dolgotrajno oskrbo - novo gradivo št. 1. Generalni sekretariat Vlade republike Slovenije. 1-12.

20. Lah, L., Svetin, I. \& Razpotnik, B. (2013, 15. september). Starejši na trgu dela. Ljubljana: Statistični urad Republike Slovenije. Pridobljeno na https://www.stat.si/doc/pub/starejsi.pdf (14. 9. 2018).

21. Lund, T., Iversen, L. \& Poulsen, K. B. (2001). Work Environment Factors, Health, Lifestyle and Marital Status as Predictors of Job Change and Early Retirement in Physically Heavy Occupations. American Journal of Industrial Medicine, 40, 161-169.

22. Mali, J. (2009). Spremembe v institucionalnem varstvu starejših: Starejši ljudje v družbi sprememb. Zbirka Dialogi, 10, 95-106.

23. Ministrstvo za delo, družino, socialne zadeve in enake možnost [MDDSZ]. (2010). Predlog Zakona o dolgotrajni oskrbi in zavarovanju za dolgotrajno oskrbo. Pridobljeno na http://www.mddsz.gov.si/fileadmin/mddsz.gov.si/pageuploads/dokumenti_pdf/ZDOZDO_uvod cleni_in_obrazlozitve_-_12.03.2010.pdf

24. Ministrstvo za delo, družino, socialne zadeve in enake možnost [MDDSZ]. (2015). Zakon o dolgotrajni oskrbi, osebni asistenci in zavarovanju za dolgotrajno oskrbo. Ljubljana. MDDSZ. 
Pridobljeno na

https://www.google.hr/search?q=95.+Ministrstvo+za + delo\%2C+družino\%2C+socialne+zadeve $+\mathrm{i}$ $\mathrm{n}+$ enake+možnost+\%5BMDDSZ\%5D.+(2015).+Ocena + prejem

25. Nagode, M., Zver, E., Marn, S., Jacović, A. \& Dominkuš, D. (2014). Dolgotrajna oskrba - uporaba mednarodne definicije v Sloveniji. Pridobljeno na http://www.umar.gov.si/fileadmin/user_upload/publikacije/dz/2014/DZ_02_14p.pdf

26. Nagode, M., Lebar, L.,\&Kovač, N. (2014). Pregled izvajanja socialne oskrbe na domu po evropskih državah s poudarkom na ocenjevanju potreb uporabnikov. IRSSV, MDDSZ, izdaja 01, Ljubljana, $1-81$.

27. OECD. (2007). Conceptual Framework and Methods for Analysis of Data Sources for Long- term Care Expenditure. Paris: OECD Publishing. Pridobljeno na https://www.oecd.org/els/health systems/Conceptual\%20Framework\%20and\%20Methods\%20for\%20Analysis\%20of\%20Data\%20 Sources\%20for\%20Long-Term\%

28. OECD. (2013). Monitoring and Improving Quality in Long-term Care. Kraj izdaje: založba ali povezava. Paris. OECD Publishing.

29. Paul, C., Ribeiro, O. \& Teixeira, L. (2012). Active Ageing: An Empirical Approach to the WHO Model. Current Gerontology and Geriatrics Research. doi:10.1155/2012/382972.

30. Paz Ballesteros, W. C., Monterrubio Flores, E. A., Flores Rivera, J., Corona Vazquez, T. \& Hernandez Giron, C. (2017). Cigarette Smoking, Alcohol Consumption and Overweight in Multiple Sclerosis: Disability Progression. Archives of Medical Research. Elsevier, 48, 113-120.

31. Prakash, K. C., Neupane, S., Leino-Arjas, P. B., von Bonsdorff, M., Rantanen, T. E., von Bonsdorff, M., Seitsamo, J. ... Nygard, C. H. (2016). Midlife job profiles and disabilities in later life. A 28-year follow- up of municipal employees in Finland. Int Arch Occup Environ Health, 89, 997-1007. doi: 10.1007/s00420-016-1133-7

32. Pravilnik o metodologiji za oblikovanje cen socialno varstvenih storitev [PMOCSS]. (2006, 17. avgust). Uradni list RS št. 87/06, 127/06, 8/07, 51/08, 5/09, 6/12.

33. Pravilnik o minimalnih tehničnih zahtevah za izvajalce socialnovarstvenih storitev. (2006, 29. april). Uradni list RS, št. 67/2006.

34. Pravilnik o postopkih pri uveljavljanju pravice do institucionalnega varstva. (2007, 15. maj). Uradni list RS št. 42/2007.

35. Pravilnik o standardih in normativih socialnovarstvenih storitev. (2010, 4. april). Uradni list RS, št. 52/95, 2/98, 19/99, 28/99 popr., 127/03, 125/04, 120/05 - Odl. US: Uradni list RS 192/05-29, 60/05, 120/05, 2/06 popr., 140/06, 120/07, 90/08, 121/08, 53/09 in 45/10. Uradni list RS, št. 45/10, 28/11, 104/11, 111/13.

36. Predlog predpisa Zakon o dolgotrajni oskrbi. (2017). Predpis v pripravi znotraj ministrstva. Pridobljeno na https://e-uprava.gov.si/drzava-in-druzba/e-demokracija/predlogipredpisov/predlog-predpisa.html?id=7885

37. Predlog zakona o dolgotrajni oskrbi in zavarovanju za dolgotrajno oskrbo. (2017, 11. junij). Pridobljeno na http://www.mddsz.gov.si/fileadmin/mddsz.gov.si/pageuploads/dokumenti pdf/zdozdo uvodcleniinobrazlozitve12.03.2010.pdf (20.7.2017).

38. Rant, M. ( 2012). Samostojnost in pomoč starim ljudem pri vsakodnevnih opravilih. Kakovostna starost, 15(3), 33-42.

39. Resolucija Evropskega parlamenta o dolgotrajni oskrbi. Charter of fundamental rights of the european union, 2000/c 364/01. (2016, 29. julij) Pridobljeno na www.europarl.europa.eu/charter/pdf/text_en.pdf 
40. Resolucija o nacionalnem programu socialnega varstva za obdobje 2013-2020 [ReNPSV13-20]. (2013, 6. maj). Uradni list RS št. 39/13.

41. Rupel Prevolnik, V. \& Ogorevc, M. (2010). Long-term care system in Slovenia. Institute for Economic Research. Enepri Research Report No. 87. Pridobljeno na http://www.ancienlongtermcare.eu/sites/default/files/Slovenia.pdf https://mail.google.com/mail/u/1/\#inbox/FMfcgxvzKkvdMsglDcxwHVktfNQKmZDx?projector= $1 \&$ messagePartId $=0.1$

42. Siegel, J. S. (2012). The Demography and Epidemiology of Human Health and Aging. Netherlands: Springer. doi. 10.1007/978-94-007-1315-4 6

43. Štuhec, J. \& Fras, M. (2010). Različne oblike bivanja za tretjo generacijo. Kakovostna starost. Revija za gerontologijo in medgeneracijsko sožitje, 13(3), 3-15.

44. Nursing Facilities fort he 21 st. Century. The department of disabilities, aging and independent living. (2007). The Green House Project. (2005). Traditional nursing home compared to the green house. Physical Elements of the Green House nursing home model. Pridobljeno na http:/ /www.thegreenhouseproject.com/index.htm

45. The Social Protection Committee. (2010). A voluntary European quality framework for social services. Pridobljeno na ec.europa.eu/social/BlobServlet?docId=6140\&langId=en

46. Poročilo o razvoju 2015. (2015). UMAR. Pridobljeno na http://www.umar.gov.si/fileadmin/user_upload/publikacije/pr/2015/POR_2015.pdf.

47. Uredba (EU) Evropskega parlamenta in sveta o varstvu posameznikov pri obdelavi osebnih podatkov in o prostem pretoku takih podatkov ter o razveljavitvi Direktive 95/46/ES (Splošna uredba o varstvu podatkov) (2016/27.april). Pridobljeno na https://eur-lex.europa.eu/legalcontent/SL/TXT/?uri=uriserv:OJ.L_.2016.119.01.0001.01.SLV

48. World Health Organization [WHO]. (2015, 22. junij). Global Age-friendly Cities: A Guide. Pridobljeno na http://www.who.int/ageing/publications/Global_age_friendly_cities_Guide_English.pdf.

Marta Kavšek je doktorirala na področju managementa kakovosti na Fakulteti za organizacijske študije v Novem mestu. Je predavateljica Fakultete za zdravstvo Angele Boškin Jesenice, kjer poučuje zdravstveno nego bolnikov s kroničnimi boleznimi - nosilka predmeta dolgotrajna oskrba in evalvatorica nacionalnih visokošolskih programov s področja zdravstva. Njene raziskovalne teme vključujejo upravljanje zdravstvenega varstva, posebno pozornost do zdravstvene nege in oskrbe starejših oseb in oseb z boleznijo demenca. Ukvarja se $\mathrm{s}$ profesionalizacijo in razvojem kakovosti zdravstvenega varstva $\mathrm{v}$ visokem šolstvu.

$* * *$

Marija Ovsenik je redna profesorica in strokovnjakinja na področju organizacije, ravnanja z ljudmi in socialne gerontologije. Doktorirala je na Fakulteti političnih ved Veljko Vlahović v Sarajevu in na Fakulteti za organizacijske študije v Novem mestu, na Univerzi v Ljubljani pa je opravila specializirano izobraževanje na področju menedžmenta človeških virov v neprofitnih organizacijah. Leta 1996 ji je Ministrstvo za delo, družino in socialne zadeve podelilo nagrado za izjemne uspehe na področju socialnega varstva.

$$
* * *
$$

David Bogataj je izredni profesor na Novi Univerzi, kjer je nosilec predmeta Socialna infrastruktura ter nosilec predmeta Maintenance Management na Univerzi v Padovi v Italiji. Prvi doktorat znanosti je prejel na področju prava in upravljanja nepremičnin na Evropski Pravni fakulteti. Na Fakulteti za organizacijske študije v Novem mestu, je doktoriral z disertacijo "Model amortizacije človeških virov". Izvaja raziskave na področju aktuarskega 
modeliranja, socialne infrastrukture in obvladovanja rizikov $\mathrm{v}$ industrijskih sistemih. Je predstojnik (Chair) Mortality Task Force v Evropskem aktuarskem združenju v Bruslju in slovenski predstavnik v Health Committee Mednarodnega aktuarskega združenja s sedežem v Ottawi. Je eden vidnejših znanstvenikov v programski skupini P5-0398 na Ekonomski fakulteti Univerze v Ljubljani in v svoji projektni skupini vodi člane treh fakultet Univerze v Ljubljani: FGG, FSD in EF. Je tudi evalvator italianskih nacionalnih raziskovalnih projektov s področja managementa in organizacije inndustrijskih sistemov.

$* * *$

\section{Abstract: An Evaluation of the Lifestyle and Spatial Needs of the Elderly}

Research Question (RV): Older people become dependent on the help of others at different ages. The question is, how lifestyle activities during lifetime influence self-sufficiency in old age. That is why we have examined in particular the impact of heavy physical work at the workplace on the age of entering long-term care and which type of dwelling prefer older adults.

Purpose: The purpose of the article is to determine whether a lifestyle - especially hard physical work - affects the age of entering long-term care and in which type of dwelling they want to be provided when they can no longer live in their own home. The findings are essential in shaping demand projections for long-term care services. Based on these, in the long run, long-term care capacities are planned, human resources are needed, and the built-in space is provided for the provision of quality care for people dependent on the help of others.

Method: We surveyed 198 elderly adults, 100 residents in Slovenian homes for the elderly, and 98 users of homecare. The respondents were classified into different groups by their lifestyle and in particular, studied the type of work they performed in the active age. We used $\mathrm{z}+4$ test to show there are statistically significant differences in age of entry to long term care facilities.

Results: We have come up with two crucial conclusions that arduous physical work significantly affects early entry into institutional care and most of older adults do not want to receive care in their home when they come to a state that they can no longer take care of themselves. With low pvalue, we can also say that most of the elderly do not want to be at home when they come to a state that they can not take care of themselves, which is contrary to the findings of the European Commission.

Organisation: Workers who have performed particularly arduous work become dependent on the help of others much earlier, which is also associated with higher expenditures for long-term care. The article deals with an example of a model for evaluating the differences in the actuarial present value of these expenditures, which can be the basis for calculating the insurance premium for occupational long-term care insurance.

Company: For the provision of long-term care services, the company should allocate appropriate resources or a proper share in GDP.

Originality: We demonstrated how, through the knowledge of the lifestyle of the population - the impact of arduous physical work influences the age of entering long-term care. With this insight, policymakers are can better plan the development of services, facilities, human resources and care networks for older adults dependent on the help of others.

Limitations/further research: Given the vulnerability of the population studied, we managed to obtain answers only from a small number of older adults. Consequently, the estimates of the parameters are worse, but the recently developed $\mathrm{z}+4$ test enables a reasonably reliable assessment of the diversity of the parameters and shows the importance of the parameters in the planned systems long-term care planning is not yet evident.

Keywords: long-term care, lifestyle, home care, sheltered housing, institutional care, social welfare institution, decline in functional capacities, assisted living facilities.

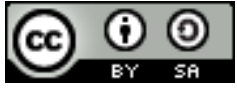

Creative Commons License

This work is licensed under a Creative Commons Attribution-ShareAlike 4.0 International License. 